\title{
POLITIKE POVIJESTI U ESTONIJI I HRVATSKOJ: DRUGI SVJETSKI RAT KAO "PROŠLOST KOJA NIKAD NEĆE PROĆI"?!
}

\section{Luka Jušić}

Fakultet političkih znanosti

Sveučilišta u Zagrebu

E-mail: lukajusic@gmail.com

\section{Stevo Đurašković}

Fakultet političkih znanosti

DOI: 10.20901/an.14.06

Sveučilišta u Zagrebu

Pregledni rad

E-mail: sdjuraskovic@fpzg.hr

Prihvaćeno: ožujak 2018.

\begin{abstract}
Sažetak U članku se uspoređuju politike povijesti Drugoga svjetskog rata u Estoniji i Hrvatskoj poslije državnog osamostaljenja. Pokazujući kako su estonski i hrvatski nacionalno-integracijski procesi dominantno bili obilježeni "potragom" za samostalnom državom, temeljna je teza članka da revizionističko sjećanje na estonske i hrvatske osovinske borce kao na "borce za naciju i državu" opstaje zbog isključivog shvaćanja Sovjetskog Saveza i Jugoslavije kao velikoruske odnosno velikosrpske "tamnice" estonskoga i hrvatskog naroda. lako službeno sjećanje u objema zemljama ističe europsko antifašističko nasljeđe, oklijevanje vlasti u odmicanju od ekskluzivističkih državotvornih politika povijesti potiče pozitivnu interpretaciju estonskoga i hrvatskog fašizma. Autori zaključno prikazuju razlike među dvjema zemljama te upućuju na pogubnost aktualnih europskih politika spram totalitarizma kao obrasca suočavanja s Drugim svjetskim ratom, a koje Estoniju i Hrvatsku još više udaljuju od suočavanja s prošlošću.
\end{abstract}

Ključne riječi Estonija, Hrvatska, Drugi svjetski rat, politike povijesti, sjećanje

\section{Uvod}

Povijest Drugoga svjetskog rata u Estoniji i Hrvatskoj umnogome se razlikuje. Između dva svjetska rata neovisnu

1 Članak je nastao na temelju rada Luke Jušića "Drugo sjećanje u Estoniji: sukob pamćenja, simbola i spomenika", koji je napisan pod mentorstvom Steve Đuraškovića u sklopu predmeta Politike povijesti na Studiju politologije na Fakultetu političkih znanosti u Zagrebu 2016/2017. akademske godine. Zahvaljujemo se na trima iznimno korisnim recenzijama koje su nam pomogle da poboljšamo rad.
Estoniju, u skladu sa sporazumom Hitler-Staljin iz kolovoza 1939, okupirao je Sovjetski Savez, da bi s agresijom nacističke Njemačke na Sovjetski Savez 1941. sovjetskoga okupatora zamijenio njemački. Napredovanjem Crvene armije 1944-1945. Estonija je doživjela drugu sovjetsku okupaciju i postala federalna jedinica Sovjetskog Saveza u kojemu je ostala do 1991. kada je proglasila neovisnost. Nakon agresije Sila osovine na Kraljevinu Jugoslaviju u travnju 1941. stvorena je Nezavisna Država Hrvatska (NDH), koja je obuhvaćala teritorij 
koji se otprilike poklapao s područjima suvremene Hrvatske i Bosne i Hercegovine. Krajem rata 1945. stvorena je Narodna Republika Hrvatska, kasnije Socijalistička Republika Hrvatska, kao federalna jedinica socijalističke Jugoslavije u kojoj je ostala do proglašenja neovisnosti 1991. Unatoč povijesnim razlikama, Estonija i Hrvatska imaju vrlo slične obrasce odnosa prema Drugome svjetskom ratu. U objema zemljama postoje snažne tendencije da se Hrvati i Estonci koji su se borili na strani Sila osovine prikažu ponajprije kao antikomunistički borci za naciju, što je povezano s interpretacijom "koja je išla sve do novog shvaćanja savezništva s nacističkom Njemačkom kao svojevrsne preteče neovisnosti, realizirane nakon 1989." (Francois 2006: 233). Iako nacistička okupacija nije vratila Estoniji neovisnost i nije uspostavila stvarnu državnu neovisnost Hrvatske, politiku sjećanja na Drugi svjetski rat i u Estoniji i u Hrvatskoj obilježava prikaz estonskih pripadnika SS-a i članova ustaškog pokreta kao boraca za naciju te izjednačavanje komunizma s ruskom odnosno srpskom hegemonijom. Shvaćanje komunizma kao "smrtne opasnosti za nacionalno biće" zajedničko je obilježje nacionalno-integracijskih procesa u Srednjoj i Istočnoj Europi općenito, ali je osobito izraženo u "nacijama bez država" u 20. stoljeću (Bibó 1995: 44-45). Estonija je odabrana kao komparativni slučaj zato što su obrasci politika povijesti sličniji hrvatskima nego u drugima dvjema baltičkim zemljama, ${ }^{2}$ dok je drugi najslični-

Letonci i Litavci mnogo su manje bili zastupljeni u nacističkima kolaboracionističkim postrojbama - lokalnim milicijama i jedinicama SS-a - od Estonaca (Auers 2015: 146-147), budući su nacisti Estonce smatrali rasno najbližima Nijemcima pa su, nasuprot Letoncima i Litavcima, tijekom rata imali autonomnu kolaboracijsku vladu (Omavalitsus) u sklopu koje su djelovale policijske i sigurnosne snage, dok su estonske jedinice SS-a nosile estonska ji slučaj, Slovačka, poznatiji i obrađeniji (Đurašković 2016a). ${ }^{3}$

Kako istraživanja politike povijesti koja, ukratko, proučavaju "tko se i u koju svrhu služi političkom interpretacijom povijesti" (Cipek 2007: 14) - pripadaju kulturološkom pristupu politici koji izučava kako kultura kao sustav simboličnih praksi utječe na politički sustav i političke procese, u radu se koristi kulturalni pristup komparativnoj analizi koji, nasuprot klasičnoj komparativnoj političkoj znanosti, primjenjuje interpretativne metode komparativne povijesti - deskripciju i interpretativnu analizu (Đurašković 2013: 39-41). Iako Haupt i Kocka (2004: 150-151) povezuju dva osnovna tipa povijesne komparacije - "tip koji ponajprije služi kontrastnim svrhama... i tip koji pospješuje uvid u podudarnosti" - $\mathrm{s}$ Millovim metodama razlike i slaganja, autori naglašavaju da se komparativna povijest razlikuje od Millove metode po tome što "sama usporedba nije metoda u strogom smislu te riječi nego je prije perspektiva". U tom smislu, perspektiva ove

nacionalna obilježja i koristile estonski kao zapovjedni jezik (Birn 2001: 182-193). Iako su sve tri baltičke zemlje za vrijeme dviju sovjetskih okupacija bile pod udarom staljinističke politike masovnih deportacija, čistki i ubojstava (Kuddyte 2012; Komisija 2004, 2008), sjećanje na sovjetsku okupaciju kao na rusku hegemoniju snažnije je u Estoniji nego u Letoniji i Litvi upravo zbog ratne autonomije, ali i zbog većih razmjera poslijeratnog naseljavanja ruskog stanovništva u Estoniju nego u Letoniju i osobito u Litvu (Bishop 2005: 77-79). U Letoniji je od 1998. do 2000. postojao službeni državni praznik kojim se obilježavalo sjećanje na pale letonske SS-ovce, a koji danas neslužbeno obilježavaju samo desničarske organizacije (Traynor 2010).

3 Sličan bi bio slučaj Ukrajine, ali nacionalno-integracijski procesi u Ukrajini bili su obilježeni podjelom na zagovornike ruskoga i ukrajinskog nacionalnog identiteta, pa je prema tome Ukrajina najsličnija Crnoj Gori. U slučaju hrvatskoga jugoslavizma, dominantna hrvatska nacionalna svijest nije bila upitna (Gross 1981). 
komparacije donekle je asimetrična zato što je primaran interes "bolje razumijevanje određenih pitanja u povijesti jedne zemlje" (Kocka 2004: 257), u ovom slučaju Hrvatske, pa je estonski slučaj referentan u odnosu prema hrvatskome.

Naposljetku, valja ukratko objasniti pojmove politika povijesti, politika sjećanja i kultura sjećanja. Politika povijesti kao znanstvena disciplina analizira uporabu raznih sadržaja povijesti u političkim sučeljavanjima, odnosno u legitimiranju i delegitimiranju određene političke pozicije, pri čemu je naglasak na objašnjenju "koji se povijesni događaji i zašto ispostavljaju kao politički važni" (Cipek 2007: 13). Pritom se gleda na to kako politička uporaba povijesti djeluje na stvaranje kulture sjećanja, koju je Jörn Rüsen odredio kao artikulaciju povijesne svijesti u svakodnevici posredstvom interpretacije prošlosti koja služi samodefiniranju društva i projekciji njegove budućnosti, te ju je nazvao povijesnom kulturom (Đurašković 2008: 203). Politički režimi mogu koristiti razne politike povijesti odnosno politike sjećanja - ta se dva termina često koriste kao istoznačnice - koje mogu voditi k stvaranju autoritarne ili građanske demokratske kulture sjećanja. Potonju karakterizira proces suočavanja s prošlošću diktatura u postdiktatorskim društvima sveobuhvatnim mjerama: od pravnog procesuiranja počinitelja zločina i rehabilitacije žrtava nasilja do sveobuhvatna poučavanja o karakteru i posljedicama diktatorskih režima (Đurašković 2013: 36). ${ }^{4}$

\section{Povijesno nasljeđe u izgradnji estonske i hrvat- ske nacije od 1990.}

Izgradnja estonske i hrvatske nacije uvelike se zasnivala na fetišizacije dr-

4 Podrobnije objašnjenje pojmova politike povijesti, politike sjećanja, kultura sjećanja i suočavanja s prošlošću u: Đurašković 2013: 30-45. žavnosti koja proizlazi iz povijesnog nasljeđa. Estonija i Hrvatska bile su dijelovi višenacionalnoga Ruskog odnosno Habsburškog Carstva. Dok je u Ruskom Carstvu proces izgradnje neruskih nacija bio potpuno ugušen, u Habsburškom Carstva puna izgradnja nacija bila je ometana na različite načine (Taylor 1990: 20-31). Dok je 1918. politička autonomija koju je Hrvatska imala u sastavu Habsburške Monarhije ugašena stvaranjem Kraljevine Srba, Hrvata i Slovenaca, baltičkim je nacijama svršetak Prvoga svjetskog rata donio neovisne države. Slijedom sporazuma Hitler-Staljin iz kolovoza 1939, Sovjetski Savez okupirao je baltičke zemlje i odmah počeo provoditi staljinistički teror koji je uključivao masovne deportacije lokalnog stanovništva u Sibir te egzekucije pripadnika političke, društvene i intelektualne elite (Auers 2015). Iako Treći Reich nije nakon napada na Sovjetski Savez 1941. obnovio državnost baltičkih zemalja u sklopu osovinske Europe, u Estoniji je osnovana kolaboracijska vlada (Omavalitsus). Istodobno, 1941. uspostavljena je Nezavisna Država Hrvatska (NDH) koju su priznale Sile osovine i njihovi saveznici. S obzirom na iskustva sovjetske okupacije 1940-1941. i života u monarhijskoj Jugoslaviji 19181941, dijelovi estonskoga i hrvatskog pučanstva dočekali su Wermacht kao osloboditelja jer su - unatoč neslaganjima s nacističkom okupacijom, odnosno s ustaškim režimom - u sovjetskoj i jugoslavenskoj komunističkoj vlasti vidjeli smrtnu prijetnju vlastitim nacijama i državnostima. ${ }^{5}$ Ta percepcija nije bila

5 Pääbo (2015) navodi da su Estonci slavili dolazak jedinica Wermachta u ljeto 1941. jer su mislili da im one nose oslobođenje od terora, dok je u strahu od obnove terora od 75.000 do 80.000 estonskih civila pobjeglo u Švedsku i Njemačku pred sovjetskom vojskom 1944-1945. Bilandžić (1999: 190) tvrdi da ukorijenjenost NDH-ovske opcije "među Hrvatima nije bila mala. Argument za tu tezu jest i činjenica da su oružane snage 
bez temelja: poslije rata iz Estonije je deportirano oko 150.000, a u čistkama je nestalo još oko 100.000 ljudi (Lehti i dr. 2008: 6), ${ }^{6}$ dok je u Hrvatskoj pogubljeno oko 50.000 pripadnika vojske NDH i civila (Žerjavić 1989: 75-79).

Komunističke diktature u Sovjetskom Savezu i Jugoslaviji potisnule su sjećanja poraženih te nametnule mit o Velikome domovinskom ratu odnosno o Narodnooslobodilačkoj borbi (NOB). Manihejska priroda obaju mitova - sadržana u interpretaciji rata kao patriotske borbe sovjetskih ljudi za slobodu i neovisnost socijalističke domovine protiv njemačkih fašista i domaćih izdajnika, odnosno u interpretaciji rata kao oslobodilačke borbe južnoslavenskih naroda, predvođenih komunistima, protiv fašista i domaćih izdajnika - "opravdavao je osvetu i implicirao da među pobeđenima nema nevinih žrtava", stvarajući na poraženoj strani "žudnju za osvetom nad komunistima i drugim protivničkim grupama" (Perica 2006: 230). U oba slučaja poraženi su kao neprijatelje primarno percipirali komuniste, koji su najčešće poistovjećivani s Rusima odnosno sa Srbima. Percepciju o ruskoj okupaciji Estonije, osim zločina, pojačavalo je doseljavanje pučanstva iz drugih krajeva Sovjetskog

NDH do posljednjeg dana bile jednako brojne kao i hrvatska partizanska projugoslavenska vojska". U oružanim snagama NDH (HOS) bilo je 1945. oko 130.000, a u hrvatskoj partizanskoj vojsci (NOVH) oko 150.000 vojnika, pri čemu su 60,4 posto bili Hrvati, što znači kako je u partizanskoj vojsci bilo oko 90.000 etničkih Hrvata (Bilandžić 1999: 182).

6 Prva sovjetska okupacija Estonije 19401941. obilježena je valom masovnih egzekucija pripadnika estonske vojne, političke i intelektualne elite, a deportirano je oko 10.000 ljudi. Druga sovjetska okupacija Estonije nastavlja se politikom kolektivizacije, nacionalizacije i čistki, ali tada su glavne mete bile obitelji bivših osovinskih boraca i malobrojni Nijemci u Estoniji (Komisija 2008: 2, 8).
Saveza, pri čemu je broj doseljenika bio podjednak broju Estonaca koji su stradali u čistkama - oko 250.000 ljudi (Kus i dr. 2013: 426). Iako je pučanstvo najviše doseljavano zbog nedostatka radne snage $\mathrm{u}$ industriji i javnom sektoru, većina doseljenika bili su Rusi koji nisu imali potrebu naučiti estonski jezik zato što je ruski bio službeni jezik u cijelome Sovjetskom Savezu. Oni su činili, otprilike, polovinu članstva Komunističke partije Estonije, što je dodatno pothranjivalo narativ o ruskoj hegemoniji nad Estoncima (Lehti i dr. 2008: 6-9). Nadzastupljenost Srba u članstvu Komunističke partije Hrvatske te u državnima i javnim službama socijalističke Hrvatske - iako je bila znatno manja od zastupljenosti Rusa u Komunističkoj partiji te u državnoj i javnoj upravi Estonije ${ }^{7}$ - pohranjivala je hrvatski narativ o velikosrpskoj hegemoniji. Iako su Estoniji i Hrvatskoj bila priznata prava na nacionalni identitet i državnost u sklopu dviju komunističkih federacija, što je i omogućila međunarodno priznanje njihove državne neovisnosti 1991. i 1992, autokratske komunističke politike sjećanja stvorile su plodno tlo da državotvorni protunarativi dobiju status (polu)službenih sjećanja nakon sloma komunističkih poredaka.

\footnotetext{
Srbi su u SR Hrvatskoj prosječno činili oko 15 posto pučanstva i oko 28 posto članstva Komunističke partije Hrvatske. Nadzastupljenost Srba u partiji, državnima i javnim službama može se tumačiti političkim i ekonomskim razlozima. Politički, velika većina hrvatskih Srba pridružila se Titovu partizanskom pokretu, dok su Hrvati bili rascijepljeni između ustaštva i partizanstva. Ekonomski, hrvatski Srbi nastanjivali su najzaostalije krajeve Hrvatske, dok su ekonomski zaostali krajevi s hrvatskom većinom dobrim dijelom u ratu bili ustaški, dakle nepodobni kao izvor regrutacije državnih i javnih službenika. Vrlo dobru analizu nacionalne zastupljenosti u službama SR Hrvatske napisao je Radelić (2006: 249-268).
} 


\section{Politika povijesti u Estoniji: sjećanje na sovjetsku okupaciju kao izvor povijesnog revizionizma}

Gorbačovljeve reforme u Sovjetskom Savezu krajem osamdesetih godina i proces mirnog proglašenja državne neovisnosti Estonije u kolovozu 1991. omogućili su javno izražavanje potisnutih sjećanja i antikomunističkih narativa. S obzirom na veliku rusku manjinu koja je činila četvrtinu pučanstva Estonije ${ }^{8}$ i podijeljena sjećanja na razdoblja nacizma i komunizma, nova država pokušala je naći izlaz u konstruiranju osnivačkog mita o neovisnoj Estoniji kao nastavku međuratne republike. Povijest Prve Republike "očišćena" je od razdoblja diktature tridesetih godina, ${ }^{9}$ a uporište osnivačkog mita postao je Rat za neovisnost 1918-1920. u kojemu su se protiv boljševika zajedno borili ruski bjelogardejci, Estonci i estonski Nijemci. Vlast se nadala kako se isticanjem zajedničke borbe Estonaca, estonskih Rusa i estonskih Nijemaca protiv crvenog totalitarizma, praćena osudom zločina što su ih počinile milicijske jedinice estonske kolaboracij-

8 U suvremenoj Estoniji etnički Estonci čine oko 66 posto, a Rusi oko 25 posto stanovnika, dok su u međuratnom razdoblju Estonci činili oko 88 posto stanovnika (Kus i dr. 2013: 426).

9 Obrazlažući zabranu podizanja spomenika generalu Johanu Leidoneru, vrhovnom zapovjedniku estonske vojske u doba diktature Konstantina Patsa, koji je pogubljen 1946, estonska predsjednica Kersti Kaljulaid izjavila je kako su general Laidoner i predsjednik Pats bili razlozi za okupaciju estonske države 1939. Nedoumice u sjećanjima na razdoblje diktature izbile su na vidjelo kod usvajanja Ustava neovisne Estonije 1991. kada su stranke desnice zahtijevale da se na snagu vrati Ustav iz 1930. Novi Ustav tako je nastao kao osuvremenjena inačica posljednjega demokratskog Ustava iz međuratnog razdoblja (Pääbo 2008: 10-11). ske vlade ${ }^{10}$ može formirati zajednički identitetni narativ koji bi bio prihvatljiv svim stanovnicima Estonije (Lehti i dr. 2008: 9-10). No taj je narativ kolidirao $\mathrm{s}$ konceptom nacionalnog pomirenja prema kojemu je Estonija bila žrtva dviju okupacija totalitarnih država. Prema tome narativu, Drugi svjetski rat bio je Estoniji nametnut pa su estonski SS-ovci, koji su većinom prisilno mobilizirani, prikazivani ponajprije kao borci za slobodu od sovjetske okupacije, dok su Estonci u redovima Crvene armije prikazivani kao vojnici koji su bili mobilizirani protiv svoje volje. ${ }^{11}$ Taj je koncept automatski rehabilitirao estonske SS-ovce kao, u konačnici, borce za naciju, dok je u drugi plan potisnuta odgovornost za sudjelovanje u ratu na nacističkoj strani. ${ }^{12}$ Tome revizionističkom sjećanju vjetar u leđa daju dužnosnici najsnažnije estonske stranke, konzervativne Pro Patria Res Publica, koji vrlo često nazoče komemoracijama za pale estonske SS-ovce. ${ }^{13}$ Martin Laar,

10 Tijekom nacističke okupacije u Estoniji je stradalo oko 7.800 estonskih državljana, među kojima je bilo oko 1.000 Židova i oko 800 Roma. Osim toga, ubijeno je od 8.000 do 10.000 Židova koje su nacisti deportirali u estonske logore iz drugih zemalja. Nacistima su u uništenju Židova pomagale milicijske jedinice, koje je osnovala estonska kolaboracijska vlada Omakaiste (Samoobrana), i sigurnosna policija (Birn 2001).

11 Oko 50.000 etničkih Estonaca mobilizirala je Crvena armija u povlačenju iz Estonije u jesen 1941, a koje je koristila kao borce u prvim redovima u ofenzivi na Estoniju 1944. Procjenjuje se da su samo trećinu od 70.000 estonskih SS-ovaca činili dobrovoljci (Pääbo 2015).

12 Predsjednica Kaljulaid u navedenoj je izjavi ostavila mogućnost podizanja zajedničkog spomenika svima "koji su zadužili Estoniju", rekavši "kako je istina da djela svih treba promatrati u kontekstu vremena, ali je neporeciva činjenica da su djela Patsa i Laidonera dovela do tragičnih posljedica" (ERR 2017).

13 Dugogodišnji estonski premijer iz Liberalne stranke, koalicijskog partnera Pro Patrie, i 
čelnik Pro Patrie i međunarodno najpoznatiji estonski političar, koji uživa ugled najzaslužnije osobe za "estonsko ekonomsko čudo", dva je puta u parlament na glasovanje slao zakon koji bi status dobrovoljaca SS-a uredio kao status boraca za naciju, ali zakon nijednom nije prihvaćen (The Algemeiner 2012).

Glavni je razlog rehabilitacije SS-ovaca činjenica da su u nacističkim zločinima većinom sudjelovale milicijske jedinice kolaboracijske vlade, dok su estonski SS-ovci - k tome, većinom prisilno unovačeni u 20. WaffenSS Grenadier Division, zvanu i Prva estonska divizija - poglavito sudjelovali u borbama protiv Crvene armije, da bi od svršetka Drugoga svjetskog rata do polovice pedesetih godina bili dijelom baltičkih partizanskih antikomunističkih odreda zvanih "Šumska braća". "Šumska braća" nastala su spajanjem raznih antikomunističkih jedinica nakon ulaska Crvene armije u baltičke zemlje sredinom 1944. Estonskoj "Šumskoj braći" daje "antifašistički sjaj" način njihova nastanka: usporedno s povlačenjem njemačkih nacističkih postrojba pred nadiranjem Crvene armije u Estoniju, posljednji prijeratni premijer Jüri Uluots - koji je 1941. odbio ponudu nacista da formira kolabo-

kasniji podpredsjednik Europske komisije Andrus Ansip na skupu veterana SS-a 2011. izjavio je kako "takvi sastanci nemaju nikakve veze s nacizmom nego s ljudima koji su branili našu zemlju, a napadi duboko vrijeđaju sve Estonce" (RT 2011). Pri podizanju spomenika SS-ovcu Alfonsu Rebaneu 2004, istaknuti parlamentarni zastupnik Pro Patrie izjavio je kako je "Rebane, prema našim povjesničarima, bio dobar vojnik i nije počinio nijedan ratni zločin, pa su napadi na njega djelo naših protivnika koji pokušavaju pokazati kako je Estonija puna fašista". Izradu i postavljanje spomenika financirao je jedan od najbogatijih estonskih poljoprivrednika Lembit Someril. Spomenik je ubrzo biti uklonjen zbog prosvjeda židovskih zajednica (Osborn 2004). racijsku vladu - javno je pozvao Estonce da formiraju Teritorijalnu obranu kako bi se borili protiv Crvene armije, a u koju je ušlo oko 80.000 ljudi, estonskih SS-ovca, pripadnika milicije kolaboracijske vlade i dobrovoljaca. Iz Teritorijalne obrane nakon svršetka rata nastala su "Šumska braća" (Bishop 2005: 76-79). Estonski Rusi "Šumsku braću" smatraju fašistima i ratnim zločincima. No činjenice da su se te postrojbe borile protiv Sovjeta neovisno o Nijemcima i da su bile formirane na poziv premijera-antifašista izbrisale su razliku između krivaca i žrtava u redovima "Šumske braće", učinivši ih pogodnima da postanu simbolom "žrtava-boraca za domovinu" (Pääbo 2015). ${ }^{14}$

Službeno sjećanje na sovjetsku okupaciju i s njome povezanu rehabilitaciju estonskih antikomunističkih boraca stvorili su kod estonskih Rusa uvjerenje kako je nova estonska država filofašistička i neprijateljska prema ruskoj manjini (Lehti i dr 2008: 18-19). Službeni pokušaj institucionaliziranja Rata za neovisnost kao osnivačkoga državnog mita, iako se na njega gledalo kao na nastojanje da se smanje međuetničke napetosti u zemlji, ruska manjina nije prihvatila zato što je smatrala kako i taj mit stavlja naglasak na borbu protiv Rusije i ruskog naroda (Pääbo 2008: 11-12). Osjećaju neprihvaćenosti snažno je pridonio i kontroverzni Zakon o strancima iz 1995. kojim je de facto onemogućeno stjecanje državljanstva većini estonskih Rusa. $\mathrm{Na}$ ime, stjecanje državljanstva bilo je uvje-

\footnotetext{
14 Kako članovi "Šumske braće" nisu bili samo Estonci nego i ostali Balti, sjećanje na njih živo je u svim baltičkim državama. U nedavnom videozapisu, koji se pojavio na službenoj Facebook-stranici NATO-a, zapovjednik litavskih specijalnih postrojba izjavio je da se oni smatraju nasljednicima "Šumske braće". Izjava je izazvala ogorčene reakcije predstavnika ruske manjine u zemlji i uzrokovala probleme u diplomatskim odnosima s Rusijom (RT 2017).
} 
tovano, među ostalim, znanjem estonskog jezika koji većina pripadnika ruske manjine nije govorila (Auers 2015: 145146). ${ }^{15}$ Zakon o državljanstvu zapravo je predstavljao lustraciju prema nacionalnom ključu, jer je državljanstvo bilo nužan uvjet zapošljavanja u državnima i javnim službama. Naposljetku, zakon se može tumačiti i kao javna politika sjećanja na sovjetsku okupaciju kao isključivo rusku, jer je isključivao sankcioniranje etničkih estonskih komunista. ${ }^{16}$

Reagirajući na osjećaj isključenosti, estonski Rusi službenom su sjećanju suprotstavili vlastito sjećanje u obliku očuvanja sovjetskog mita o Velikome domovinskom ratu, a što se najsnažnije izrazilo u "ratu spomenika". Rat je izazvan time što su razne nacionalističke udruge podizale spomenike estonskim SS-ovcima s natpisima "poginuli u službi domovine", istodobno pokušavajući ukloniti spomenike vojnicima Crvene armije (Lehti i dr. 2008: 22). Desničarske inicijative često su imale potporu lokalnih vlasti pa su spomenici SS-ovcima bili nanovo podizani kada bi intervencijom središnjih vlasti bili uklonjeni (Burch i

15 Zakon je uvjetovao stjecanje državljanstva time da makar jedan roditelj bude estonske nacionalnosti. Ako taj uvjet ne ispunjava, tražitelj državljanstva morao je imati najmanje 15 godina i živjeti u Estoniji najmanje osam godina od datuma podnošenja zahtjeva za državljanstvom, s tim da zna estonski jezik (Riigikogu 1995).

16 Koliko je shvaćanje sovjetskog poretka kao ruskoga okupacijskog režima bilo ukorijenjeno pokazuje činjenica da je na prvim predsjedničkim izborima 1992. bivši čelnik Komunističke partije Estonije Arnold Rüütel dobio najviše glasova birača (42 posto), ali nije postao predsjednik zato što ga je u drugom krugu izbora - u kojemu je parlament birao predsjednika države među dvojicom kandidata koji su dobili najviše glasova birača - porazio kandidat konzervativne Pro Patrie Lennart Meri. Rüütel je ipak bio predsjednik Estonije od 2001. do 2005. (Auers 2015: 145).
Smith 2007: 11). ${ }^{17}$ Najznačajniji događaj u "ratu spomenika" bilo je uklanjanje statue Brončanog vojnika u Tallinnu u proljeće 2007. Taj spomenik - podignut u samom središtu grada 1947. kako bi komemorirao ulogu Crvene armije $\mathrm{u}$ oslobađanju Estonije od fašista - bio je odlukom lokalne vlasti premješten na vojno groblje izvan grada, a mjesto spomenika ostalo je praznim (Burch i Zander 2010: 60).

Uklanjanje spomenika pratili su prosvjedi ruske manjine, koji su se nadovezali na proslavu 9. svibnja koji se u Sovjetskom Savezu slavi kao Dan pobjede nad fašizmom. Rusko stanovništvo tradicionalno je svake godine obilježavalo taj događaj skupovima kod spomenika vojnicima Crvene armije diljem zemlje, dok bi se u Tallinnu održavao središnji mimohod od vojnog groblja do Brončanog vojnika. Mimohod je 2007. prekinut zbog prosvjeda radikalne desnice, a diljem zemlje rušeni su spomenici borcima Crvene armije. Na to je ruska manjina odgovorila nasilnim protuprosvjedima i oštećivanjem spomenika borcima SS-divizija i "Šumske braće" te spomenika koji komemoriraju Rat za neovisnost. Prosvjedi su stvorili prilično usijanu političku atmosferu u zemlji, a strasti su se smirile nakon postavljanja Brončanog vojnika na vojnom groblju u Tallinnu u nazočnosti ondašnjeg premijera, gradonačelnika Tallinna i ministra obrane iz redova ruske manjine (Smith 2008; Kattago 2009). Vlast je tada priznala legitimnost dviju komemoracija Dana pobjede nad fašizmom: službene, na Europski dan pobjede nad fašizmom 8. svibnja, koji se u Estoniji slavi kao

\footnotetext{
17 Nekoliko mjeseci nakon što je prema nalogu središnje vlasti uklonjen spomenik estonskom vojniku u uniformi SS-a u gradu Lihula, gradonačelnik je dopustio da se spomenik ponovno podigne tvrdeći da on komemorira "borbu protiv većeg zla" (Kolb 2005).
} 
Dan nacionalne tragedije kada je jedna totalitarna okupacija smijenila drugu; neslužbene, 9. svibnja, koju organiziraju predstavnici ruske manjine i estonskih nevladinih udruga antifašističkog predznaka. $^{18}$

Aktualne politike službenih vlasti, koje teže miroljubivu supostojanju suprotstavljenih sjećanja, vidljive su i u Muzeju okupacija koji je otvoren 2003. Iako je stalni postav Muzeja jednak prostor dao i jednoj i drugoj okupaciji, sovjetska se okupacija prikazuje gorom zato što većina postava prikazuje strahote komunističke vlasti. ${ }^{19}$ Zbog prijepora koje je postav izazivao u javnosti, Muzej je zatvoren 2016. i podvrgnut temeljitoj rekonstrukciji koja bi trebala uvesti više sadržaja o holokaustu i nacističkoj okupaciji, a Muzej okupacija trebao bi biti preimenovan u Muzej slobode i otvoren 2018. (Weekes 2017).

18 Gradska vlast podupire i veliku proslavu Dana sjećanja na ulazak Crvene armije u Tallinn 22. rujna 1944. (Pääbo 2015).

19 S ulaza u muzej uočljive su dvije lokomotive koje simbolično označavaju krivce za okupacije Estonije, komuniste i naciste, jer na njima stoje petokraka i svastika (Wulf 2008: 226-229). Iako su obje okupacije osuđene, dijelovi nacističke okupacije prikazuju se u pozitivnijem svjetlu zato što je, kako proizlazi iz postava, ona omogućila Estoncima da se bore protiv komunizma. Na tu se okupaciju djelomice gleda i kao na, doduše propali, pokušaj uspostave samostalne Estonije te se jasno prikazuje kako je nacistička okupacija bila mnogo blaža od komunističke, među ostalim i zato što su nacisti dopustili korištenje estonskih nacionalnih simbola. Primjetno je da je glavni motiv izgradnje muzeja bio antikomunizam, a ne antifašizam, što se vidi i u uporabi nacističke propagande kao primjera strahota koje su počinili komunisti (James 2008: 22-23). U jednome od dokumentarnih filmova koji su se prikazivali u muzeju većinom se govori o strahotama koje su počinili Sovjeti za vrijeme prve okupacije Estonije (Kello i Vilu 2000).

\section{Politika povijesti u Hrvatskoj: potisnuta nacionalna sjećanja kao izvor povijesnog revizionizma}

Nasuprot Estoniji koja je neovisnost stekla mirnim putem i nije se morala odupirati nasilnim pokušajima Rusije da spriječi proces osamostaljenja, Hrvatska je neovisnost stekla u Domovinskom ratu braneći se od agresije JNA i pobune dijela hrvatskih Srba. Rat je utjecao na proces izgradnje nacionalne države, koji je obilježio mnogi radikalniji sukob većinskih etničkih Hrvata i manjinskih Srba od sukoba estonske većine i ruske manjine.

Nadalje, kako su Hrvati u Drugome svjetskom ratu bili duboko podijeljeni na pristaše antifašističkoga partizanskog pokreta, koji su predvodili komunisti koji su se zauzimali za uspostavu federativne Jugoslavije prema uzoru na Sovjetski Savez, i fašističke NDH, prvi hrvatski predsjednik Franjo Tuđman osmislio je svoj središnji koncept nacionalne pomirbe kao pomirenje ustaških i partizanskih potomaka u suvremenoj borbi za neovisnu Hrvatsku. Kao i u estonskom slučaju, Tuđman je interpretirao suprotstavljene strane kao žrtve dviju totalitarnih ideologija, ali i kao borce koji su imali sličan cilj - neovisnu Hrvatsku pri čemu je umanjio razmjere ustaških zločina tako da bi težinom, otprilike, odgovarali partizanskima (Đurašković 2016a: 62-73). Tuđmanova ideja nacionalne pomirbe imala je sličnu svrhu kao i naracija o Estoniji kao žrtvi dviju okupacija: da se prema težini krivica i zasluga za hrvatsku državnost izjednače dvije strane te tako dovede do svojevrsnoga povijesnog zaborava i okretanja Hrvata ka ujedinjenju na programu borbe za neovisnu državu, pri čemu bi Domovinski rat postao utemeljiteljski mit nove neovisne države.

Slično estonskom konceptu Sovjetskog Saveza kao države koja je isključivo 
značila rusku okupaciju Estonije, ideja pomirbe sadržavala je sliku Jugoslavije kao isključivo velikosrpske diktature nad Hrvatskom, pa je razdoblje Jugoslavije "gdje se nije smjelo reći da si Hrvat" ispalo gore od razdoblja NDH (Đurašković 2016b). Ako je temeljni kanon povijesti stvaranje samostalne države, karakter političkog režima i zločina koji su počinjeni u njemu postaju sekundarnima. Posljedično, ustaše, kao i estonski SS-ovci, mogu biti interpretirani kao žrtve-borci za neovisnu Hrvatsku. U hrvatskom slučaju tu je interpretaciju osnažila činjenica da su "komunistički zločini u pravilu... pripisivani srpskim partizanskim jedinicama" (Cipek 2007: 19), pa su "velikosrpski zločini iz 1991. služili (su) kao 'dokaz' trajne zločinačke srpsko-partizanske politike koja je na djelu bila i 1945." (Cipek 2009: 160; v. i Đurašković 2016a: 172). Takva interpretacija izvedena je iz činjenice da je JNA bila nasljednica partizanske vojske, dok je "komunistička diktatura postala u prvom redu srpski proizvod" (Cipek, 2007: 19), čime su, kao i u estonskom slučaju, hrvatski komunisti isključeni iz svih negativnih pojava režima. ${ }^{20}$ Tako je i u hrvatskom slučaju provedena svojevrsna nacionalna lustracija "čišćenjem" Srba iz hrvatskih državnih i javnih službi (Ivančić 2003; Đurašković 2016a: 152). Iako je, suprotno estonskom slučaju, Tuđman pokušao vrednovati zasluge partizanske državotvorne borbe protiv fašizma, pa je ZAVNOH naveden u Ustavu kao jedno od povijesnih uporišta hrvatske neovisnosti, to što su se hrvatski partizana borili za rješenje hrvatskog pitanja u Jugoslaviji - koju je Tuđman prikazivao kao najveće zlo u hrvatskoj povijesti - učinilo ih je drža-

20 Tako "Zakon o naknadi imovine oduzete za vrijeme jugoslavenske komunističke vlasti" uređuju povrat imovine "koja je prijašnjim vlasnicima oduzeta od strane jugoslavenske komunističke vlasti" (Hrvatski sabor 1996). votvorno deficitnima u odnosu prema ustašama (Đurašković 2016b).

"Top-down" ishod službenih politika povijesti najbolje se, kao i u Estoniji, vidio u odnosu prema politici sjećanja na bivši režim, koji bi se u hrvatskom slučaju mogao nazvati ratom protiv sjećanja na bivši režim, za razliku od rata podijeljenih sjećanja u Estoniji. Razliku je uzrokovalo to što je osamostaljenje Hrvatske bilo praćeno ratom. S obzirom na delegitimaciju simboličkog nasljeđa bivše države, prvo desetljeće hrvatske samostalnosti prošlo je u znaku brisanja politika sjećanja na bivšu državu. To je bilo najvidljivije u oštećivanju i uništenju oko polovice antifašističkih memorijala u Hrvatskoj, uključujući djela velike umjetničke vrijednosti, te u posljedičnoj poplavi ustaške ikonografije, kako na razini svakodnevice tako i na razini lokalnih, poluslužbenih politika sjećanja. Najočitiji su primjeri bila imenovanja ulica u više hrvatskih gradova po književniku i visokome ustaškom dužnosniku Mili Budaku (Durašković 2016a: 172). Središnju simboličnu ulogu dobila je Blajburška komemoracija na kojoj su se masovni zločini jugoslavenskih partizana i komunista protiv zarobljenih pripadnika osovinskih vojski 1945 . tumačili kao "hotimični genocid nad hrvatskim narodom, a ne razračunavanje novog komunističkog režima sa svim svojim političkim i ideološkim protivnicima bez obzira na njihovu etničku pripadnost" (Pavlaković 2009: 179). Komemoracija, koja je izravno rehabilitirala NDH i ustaše kao borce za Hrvatsku, dobila je državno pokroviteljstvo 1995. Istodobno je najvažnije mjesto sjećanja na ustaške zločine u Drugome svjetskom ratu, spomen-područje Jasenovac, trebalo, prema Tuđmanovoj ideji nacionalne pomirbe, biti pretvoreno u mjesto sjećanja na sve povijesne žrtve za Hrvatsku. Tuđmanova kontroverzna ideja o pretvaranju Jasenovca u spomen-pod- 
ručje prema uzoru na Francovu Dolinu palih 1996-1997. odbačena je nakon oštrih prosvjeda međunarodne zajednice, domaćih nevladinih udruga i brojnih intelektualaca (Đurašković 2016a: 173174), dok se antifašističko nasljeđe počelo revitalizirati tek nakon Tuđmanove smrti i smjene vlasti 2000 .

Tijekom vladavine reformiranog HDZ-a, a u sklopu procesa pristupanja Hrvatske Europskoj uniji, uklonjeni su memorijali ustašama postavljeni devedesetih godina, a počela je obnova oštećenih ili uništenih antifašističkih spomenika. Hrvatski Srbi opet su nesmetano mogli komemorirati mjesta masovnog stradanja Srba u ustaškom režimu (Banjeglav 2012: 110-124). Reformirani HDZ sklopio je koaliciju s predstavnicima Srba u Hrvatskoj, a spomen-područje Jasenovac postalo je središnje mjesto gdje su najviši državni dužnosnici reafirmirali antifašizam i nedvosmisleno osuđivali nasljeđe NDH, ističući kako "nema tog cilja, političkog ili nekog drugog, koji može opravdati zločin" (index.hr 2004). Iako se u Deklaraciji o antifašizmu iz 2005. navodi kako ne treba izjednačavati "antifašistički pokret s ideologijom komunizma" (Hrvatski sabor 2005, čl. 8), reformirani HDZ koji su predvodili Ivo Sanader i Jadranka Kosor nije bio sposoban to načelo provesti u političkoj praksi. To je vidljivo iz odluke Sabora 2008. da se pet puta više sredstava dodijeli komemoraciji žrtvama u Bleiburgu nego u Jasenovcu (Pavlaković 2008: 30-32) ili u zatvaranju očiju pred podizanjem spomenika koji zajednički komemoriraju pale vojnike NDH i pale branitelje iz Domovinskog rata (Banjeglav 2012: 134-137). Tako je nastavio živjeti narativ o 1991. kao nastavku 1945.

I dok posljednjih desetak godina građanska kultura sjećanja i proces suočavanja s prošlošću u Estoniji ipak napreduju - ponajviše u oblicima priznanja legitimnosti suprotstavljenih narativa i u poduzimanja određenih mjera kojima se uklanja revizionizam iz službenog sjećanja, što je najvidljivije iz slučaja Muzeja okupacija - u Hrvatskoj je posljednjih godina nastupio rat sjećanja sličan nekadašnjemu istovrsnom ratu u Estoniji. Od 2011. do 2016. HDZ pod predsjednikom Tomislavom Karamarkom nije samo odbacio politiku Ive Sanadera i Jadranke Kosor, nego je i Tuđmanov koncept pomirbe interpretiran kao "jedna velika dobronamjernost s njegove strane", koju su "zlatna mladež..., djeca ondašnjeg komunizma" iskoristili da prežive i "krenu u napad protiv svih tih istinskih hrvatskih vrijednosti" (Hudelist 2015: 18). Okrivljujući "djecu komunizma" za sve aktualne nedaće u Hrvatskoj - ona, navodno, zauzimaju ključne položaje u kulturi, medijima i gospodarstvu (Cipek 2017) - Karamarkova ideologija i politika smjerale su na konačan obračun $s$ komunističkom prošlošću u sklopu kojega bi se oslobodio prostor za ofenzivu desnog revizionizma koji odbacuje antifašističko nasljeđe kao totalitarnu i "jugokomunističku" baštinu. Hrvatski rat sjećanja razlikuje se od estonskoga po tome što drugu stranu čine razne građanske udruge i intelektualci, većinom hrvatske etničke pripadnosti, a koje podupiru i predstavnici hrvatskih Srba. ${ }^{21}$ Bitno slabija uloga hrvatskih Srba u formiranju kolektivnih sjećanja od uloge estonskih Rusa proizlazi iz nasljeđa Domovinskog rata i odlaska velikog broja Srba iz Hrvatske s okončanjem rata $1995 .^{22}$

${ }^{21}$ Jedini slučaj podijeljenog sjećanja, kao u Estoniji, tiče se Vukovara. Državna komemoracija održava se 18. studenoga, na dan kada su 1991. Vukovar okupirali JNA i paravojne postrojbe srpskih ekstremista. Nasuprot tome, srpska zajednica komemorira 19. studenoga kao dan prestanka ratnih operacija i oslobođenja Vukovara (Kadrov 2006; Đurašković 2016a: 175).

${ }^{22}$ U kojoj se mjeri odlazak Srba može nazvati prisilnim činom koji su organizirale političke vođe Republike Srpske Krajine uoči 
Aktualni hrvatski rat sjećanja može se nazvati totalnim zato što zadire u sve sfere odnosa s prošlošću. Radikalne desne revizionističke udruge pokušavaju promijeniti i karakter Spomen-područja Jasenovac od mjesta spomena na ustaške zločine u mjesto spomena na fašističke i komunističke zločine. Idejna je podloga prenamjene rehabilitacija nasljeđa $\mathrm{NDH}$, pri čemu se poriče da je Jasenovac bio ustaški logor smrti i bitno se umanjuje broj žrtava u njemu. ${ }^{23} \mathrm{Na}$ podlozi teorija totalitarizama želi se inaugurirati politika sjećanja "nultog sata" jer je, kako misli bivši ministar kulture Zlatko Hasanbegović, Domovinski rat "jedini temelj na kojem se treba graditi Hrvatska... Antifašizam nije temelj ove države već floskula koja nema utemeljenje u ustavnom tekstu..." (HRT 2016). Proglašenje antifašizma floskulom temelji se na diskreditaciji komunističkog antifašizma kao zla jednaka fašizmu. Tako je u Zagrebu uklonjen naziv Trg Maršala Tita, kojega je Tuđman postavio u nacionalni panteon kao "jednog od najvećih državnika Europe", koji je "doveo hrvatski narod na stranu pobjedničkih antifašističkih sila" i "omogućio da se stvori federalna država Hrvatska" (Sedlar

samog sloma te tvorevine, a u kojoj je mjeri bio posljedica politike etničkog čišćenja hrvatskih vlasti v. Đurašković 2016a: 155.

23 Tu akciju vodi Društvo za istraživanje trostrukog logora Jasenovac koje želi dokazati da je Jasenovac bio "radni logor za protivnike Nezavisne Države Hrvatske (u najvećem broju komuniste i njihove suradnike)", te da je "logor nastavio s radom i nakon 1945., a zatočenici su bili protivnici komunističkog režima i pobornici Staljinovog Informbiroa. Odatle i pridjev 'trostruki' u imenu društva". Članovi društva negiraju službeni broj žrtava "od oko 80000 ljudi" i tvrde da je "u logoru bilo oko 2000 zatočenika, dok je kroz njega prošlo još nekoliko tisuća osoba" (Društvo 2014). Društvu, osnovanom 2014, Ministarstvo hrvatskih branitelja dodijelilo je krajem 2017. godine "50.000 kuna za projekt u kojem će se istraživati arhivski dokumenti o logoru u Jasenovcu" (Društvo 2018).
2008). Cilj je radikalne desne ofenzive na "bauk (jugo)komunizma koji pohodi Hrvatskom" - kako je Tihomir Cipek (2017) nazvao aktualni radikalni desni povijesni revizionizam - revizija povijest kako bi se pokazalo da su ustaše bile jedini borci za naciju i državu do 1991. te da, prema tome, ne postoji "pozitivna jezgra iz tradicija hrvatske ljevice što je proklamirala pravo hrvatskog naroda na samoodređenje", kako je Tuđman (1990: 75) definirao "jednu od tri bitne sastavnice i odrednice novije hrvatske povijesti". To je vidljivo ne samo iz zahtjeva da se "iz Ustava izbaci ZAVNOH" kao "jedinog načina da detitoiziramo državu" (D.Š./V.Š. 2013), nego i iz peticije da se u Oružane snage Republike Hrvatske uvede ustaški pozdrav "Za dom spremni" koji se proglašava starohrvatskim pozdravom (Dg 2015), iako su ga u hrvatskoj povijesti koristile samo ustaše. Stvorena atmosfera omogućila je da se prvi put napadne obilježavanje Dana ustanka u Srbu, koje je osobito važno za antifašističko nasljeđe srpske manjine. ${ }^{24}$ Naposljetku, rat sjećanja problematičan je zbog još dvaju razloga. Prvo, najnoviji val desnoga povijesnog revizionizma izravno potiče dio visokih struktura Katoličke crkve u Hrvatskoj (Cipek 2017: 161-163). Drugo, HDZ pod vodstvom

24 Lokalno srpsko stanovništvo organizirano se 27. srpnja 1941. pobunilo protiv ustaškog terora. U socijalizmu se taj datum slavio kao Dan ustanka naroda Hrvatske. Predsjednik Tuđman zamijenio je taj datum Danom antifašističke borbe 22. lipnja 1941. kada je osnovan prvi partizanski odred u Hrvatskoj. Taj simboličan čin bio je dio Tuđmanova "pohrvaćivanja" antifašističkog pokreta u Hrvatskoj jer su taj odred većinom činili Hrvati (Đurašković 2016a: 171-172). Proslava 27. srpnja odvijala se pod pokroviteljstvom vlade, a bila je praćena protuprosvjedima raznih desničarskih skupina koje ustanak Srba tumače kao antihrvatski, odnosno četnički čin (Banjeglav 2012: 121-122). Tek su s HDZ-ovim skretanjem k radikalnoj desnici 2011. te skupine dobile prostor za narušavanje komemoracije (N1 Hrvatska 2016). 
Andreja Plenkovića od 2016. - unatoč deklarativnom povratku na politike povijesti s početka 21. stoljeća - ne poduzima konkretne mjere protiv ofenzive desnih revizionista. ${ }^{25}$

\section{Zaključak: povijest koja nikad neće proći?}

Istraživanja identitetskih odrednica u Estoniji 2012. pokazala su da velika većina Estonaca (86 posto) misli kako nijedna strana u Drugome svjetskom ratu nije bila ni samo negativna ni samo pozitivna, ali su ispitanici negativnije gledali na djelovanje i ulogu Crvene armije. Samo je desetak posto ispitanika smatralo da je Crvena armija nedvosmisleno bila okupatorska vojska i da su estonski SS-ovci bili borci za naciju. Istraživanje je pokazalo da je većina estonskih Rusa (92 posto) smatrala Crvenu armiju oslobodilačkom vojskom, a razdoblje Drugoga svjetskog rata jednoznačno je označavala kao doba nacističke okupacije. No istraživanje 2005. pokazalo je da se četrdesetak posto anketiranih estonskih Rusa suglasilo s tvrdnjom da je sovjetska vlast u Estoniji bila okupatorska, što je velik napredak u odnosu prema nalazima istraživanja 1995. kada je gotovo 90 posto estonskih Rusa mislilo da je Estonija dobrovoljno pristupila Sovjetskom Savezu (Kus i dr. 2013: 426429; Pääbo 2008: 11).

${ }_{25}$ Iako se HDZ riješio Karamarkova ministra kulture Zlatka Hasanbegovića, jednog od simbola koncepta antikomunističkoga i antitotalitarnog antifašizma (Czerwiński 2016), oklijevanje je pokazao u slučaju kontroverzne ploče s ustaškim grbom i pozdravom "Za dom spremni" podignute u Jasenovcu kao znak sjećanja na pale pripadnike HOS-a u Domovinskom ratu. Plenković je sučeljavanje s desnim revizionizmom i ratom sjećanja pokušao izbjeći osnutkom Vijeća za suočavanje s posljedicama vladavine nedemokratskih režima koje je imalo "zadatak donošenja sveobuhvatnih preporuka usmjerenih na suočavanje s prošlošću" do 1. ožujka 2018. (Hr.n1.info.com 2017:1).
Odatle se može zaključiti da je politika prihvaćanja podijeljenog sjećanja ipak povećala stupanj konsolidacije društva tako što je potaknula jačanje suglasja državljana o događajima koji imaju fundamentalno značenje za identitet države i nacije. Osim vladine politike u posljednjem desetljeću, konsolidaciji povijesnog sjećanja početan je poticaj dala reforma kontroverznog Zakona o državljanstvu početkom 21. stoljeća kojom je znatno ublažena klauzula o jeziku tako da je veći dio ruske manjine dobio estonsko državljanstvo, a i oni koji i prema novom zakonu nisu uspjeli dobiti državljanstvo, stekli su biračko pravo na lokalnim izborima. $\mathrm{S}$ obzirom na brojnost ruske manjine, sve su se političke stranke bile prisiljene obraćati i toj skupini u borbi za glasove (Auers 2015: 147-148). Naposljetku, konsolidaciji povijesnog sjećanja pridonijeli su i ulazak Estonije u Europsku uniju i zamjetno viši životni standard u Estoniji nego u Rusiji (Kus i dr. 2013: 13-15).

U Hrvatskoj svjedočimo obratnim trendovima pa se čini da je u posljednjem desetljeću standard demokratske kulture povijesnog sjećanja rapidno opao. Kanonsko istraživanje Ivana Šibera (1998: 63) pokazalo je korelacije između obiteljske povijesti u Drugome svjetskom ratu i političkih stavova te utvrdilo da su otprilike jednako proširena pozitivna vrednovanja partizanskog pokreta i NDH. Jedno je recentno istraživanje pokazalo da se respektivni transgeneracijski lomovi prenose i na mlade (Blanuša 2015). U anketi tjednika Globus 1995. pokazalo se da je većina anketiranih smatrala kako je NDH bila izraz povijesnih težnji hrvatskog naroda za vlastitom državom, ali i da je bila svjesna fašističke prirode ustaškog režima te nije gledala na samostalnu Republiku Hrvatsku kao na nasljednicu NDH (Gagnon 2004: 155). Snažan utjecaj Tuđmanovih ideja potvrdila su i istraživanja 2011. (Pavlaković 2014: 37). No jedno je istraživanje 2015. pokazalo 
kako "gotovo tri četvrtine učenika završnih razreda srednjih škola ne smatra da je NDH bila fašistička tvorevina" (Turčin 2015). Slični stavovi utvrđeni su i intervjuiranjem splitskih maturanata. Jedan od intervjuiranih tako je izjavio da su "ustaše najveći Hrvati, a partizani su, šta ja znam... šta bi mogli bit partizani, čekaj... Partizani, oni su isto Hrvati, ali manji Hrvati" (Pilić 2013: 3). To vodi k hipotezi kako stavovi, makar mladih, djelomice korespondiraju s ideološkim zaokretima HDZ-a. S dolaskom Tomislava Karamarka na čelo stranke, HDZ se odmaknuo od Tuđmanovih ideja koje su isticale i državotvornu vrijednost hrvatskog antifašizma i partizanskog pokreta ka konceptu antifašizma kao "floskule".

Naposljetku, nužni su preduvjeti suočavanja s poviješću Drugoga svjetskog rata dekonstrukcija službenog mita o Sovjetskom Savezu i socijalističkoj Jugoslaviji kao isključivoj velikoruskoj odnosno velikosrpskoj hegemonističkoj državi i oblikovanje službenog sjećanja koje bi obje kompleksne tvorevine prikazalo kroz "pedeset nijansi sive". ${ }^{26}$ To zahtijeva i promjenu teleološke paradigme hrvatske povijesti kao isključive tisućljetne borbe za neovisnost i hrvatske nacije kao isključive povijesne žrtve, te kontekstualno sagledavanje hrvatske povijesti koje uključuje brojne društvene, političke i kulturne aspekte. Na navedene probleme nakalemile su se teorije totalitarizma koje su posljednjih godina postale snažno političko oružje u svim europskim zemljama. Iako su europske politike suočavanja s prošlošću nacističkoga i komunističkog totalitarizma trebale

${ }_{26}$ Brubaker (1996) zorno pokazuje kako se lenjinistička politika "nacionalno u formi, socijalističko u sadržaju" provodila u Sovjetskom Savezu "institucionalizacijom etničnosti", gdje je nacionalna pripadnost bila "obvezno pripisan status". Najbolji prikaz formiranja socijalističkog hrvatstva i njegova odnosa prema konceptu jugoslavenskoga socijalističkog patriotizma dao je Radelić (2006). služiti legitimiranju liberalne demokracije kao jedine globalne alternative crnoj i crvenoj diktaturi, nenadano - ili, ipak, očekivano - dovele su do diskreditacije europskog nasljeđa antifašizma. Naime, kako se tvrdi da je komunistima antifašistička borba bila samo sredstvo revolucije, komunistički antifašizam prikazuje se lažnim. No većinu antifašističkih pokreta u Europi vodili su i dobrim dijelom činili komunisti pa se njihovim isključivanjem europsko građansko društvo mora suočiti s grijehom nečinjenja (Đurašković 2015; Cipek 2017: 165). Jednako je problematično izjednačavanje zločinačkih karaktera dvaju režima, budući da su nacistički zločini bili neprijeporno genocidnog karaktera, a komunistički nisu. ${ }^{27}$ Ako je komunistički antifašizam floskula i ako su fašistički i komunistički zločini jednaki, ništa ne sprečava da se kao službeni narativ ne usvoji mišljenje koje je pregnantno izrazio sin jednoga ustaškog borca: "Pavelić... što je Židove osudio i što je bio uz Hitlera, to nije u redu... Al' mi smo za državom, nismo za Pavelićem, mi smo htjeli svoju državu... Ipak su neki drugačije mislili ljudi..., ali mi smo uz Hitlera uspjeli dobiti državu, znate kako je, uz jačeg (Maak 2008: 5-6).

${ }_{27} \mathrm{U}$ jednoj od najcjelovitijih studija o karakteru nacističkih i komunističkih zločina, francuski povjesničar Bruneteau (2005: 53-57) utvrdio je kako se komunistički zločini razlikuju od nacističkih po tome što nisu bili genocidnog karaktera, osim gladomora u Ukrajini 1932-1933. On je definiciju genocida iz UN-ove Konvencije, prema kojoj "genocid je svako djelo počinjeno s namjerom da uništi, potpuno ili djelomično, jednu nacionalnu, etničku, rasnu ili religijsku skupinu", dopunio tako da je genocid definirao kao "oblik masovnog masakra pomoću kojeg jedna država ili neka druga vlast namjerava uništiti jednu grupu, a tu grupu i njene članove određuje počinitelj". Sukladno toj definiciji, komunistički zločini ne mogu se okarakterizirati kao klasni genocid, budući da ne postoji kriterij stabilne skupine prema kojoj bi se odredio genocid jer klasni neprijatelj nije određen precizno nego voluntaristički. 


\section{Literatura}

Auers, Daunis. 2015. Comparative Politics and the Government of the Baltic States: Estonia, Latvia and Lithuania in the 21st Century. Basingstoke: Palgrave Macmillan.

Banjeglav, Tamara. 2012. Sjećanje na rat ili rat sjećanja? Promjene u politikama sjećanja u Hrvatskoj od 1990. godine do danas. U: Karačić, Darko i dr. Revizija prošlosti: Politike sjećanja u Bosni i Hercegovini, Hrvatskoj i Srbiji od 1990. godine. Sarajevo: ACIPS i Friedrich Ebert-Stiftung, str. 91-161.

Bibó, István. 1995. Bijeda istočnoeuropskih malih država. U: Karaman, Igor, Roksandić, Drago. (ur.). István Bibó - Tibor Huszár- Jenő Szücs: Regije Europske povijesti. Zagreb: Naprijed, str. 11-93.

Bilandžić, Dušan. 1999. Hrvatska moderna povijest. Zagreb: Golden marketing - Tehnička knjiga.

Bettina, Birn Ruth. 2001. Collaboration with Nazi Germany in Eastern Europe: The Case of the Estonian Security Police. Contemporary European History. (10) 2: 181-198.

Bishop, Chris. 2005. SS: Hitlers Foreign Divisions. New York: Amber Books.

Blanuša, Nebojša. 2015. Drugi svjetski rat kao generacijska trauma: sablast prošlosti među mladima u Hrvatskoj. U: Ilišin, Vlasta i dr. (ur.). Demokratski potencijali mladih u Hrvatskoj. Zagreb: Institut za društvena istraživanja i Centar za demokraciju i pravo Miko Tripalo, str. 125-145.

Brubaker, Rogers. 1996. Nationalism Reframed: Nationhood and the National Question in the New Europe. Cambridge: Cambridge University Press.

Bruneteau, Bernard. 2005. Stoljeće genocida. Nasilje, masakri i genocidne metode od Armenije do Ruande. Zagreb: Politička kultura.
Burch, Stuart, Smith, David. 2007. Empty Spaces and the Value of Symbols: Estonia's War of Monuments' from Another Angle. Europe-Asia Studies. (59) 6: 913-936.

Burch, Stuart, Zander, Ulf. 2010. Preoccupied by the Past The Case of Estonia's Museum of Occupations. Scandia. (74) 2: 53-73.

Cipek, Tihomir. 2007. Politike povijesti u Republici Hrvatskoj; od 'puška puče' do 'Hristos se rodi. U: Cipek, Tihomir, Milosavljević, Olivera. (ur.). Kultura sjećanja: Povijesni lomovi i svladavanje prošlosti Zagreb: Disput, str. 13-27.

Cipek, Tihomir. 2009. Sjećanje na 1945: čuvanje i brisanje - o snazi obiteljskih narativa. U: Cipek, Tihomir, Bosto, Sulejman. (ur.). Kultura sjećanja: 1945. Povijesni lomovi i svladavanje prošlosti. Zagreb: Disput, str. 155-165.

Cipek, Tihomir. 2017. The Spectre of Communism is Haunting Croatia. The Croatian Right's Image of the Enemy. Politička misao. (54) 1-2: 150169.

Czerwiński, Maciej. 2016. Croatia's Ambivalence over the Past: Intertwining Memories of Communism and Fascism. Cultures of History Forum. http:// www.cultures-of-history.uni-jena.de/ debates/croatia/croatias-ambivalence-over-the-past-intertwining-memories-of-communism-and-fascism/ (pristupljeno 20. siječnja 2018).

Dg. 2015. Peticija Grabar-Kitarović i Karamarku da se "Za dom spremni" uvede u Oružane snage, 24. kolovoza 2015. https://narod.hr/hrvatska/peticija- grabar-kitarovic-i-karamarku -dase-za-dom-spremni-uvede-u-oruzanesnage (pristupljeno 16. siječnja 2018).

Društvo (Društvo za istraživanje trostrukog logora Jasenovac). 2014. O NAMA. https://drustvojasenovac.wordpress. 
com/about (pristupljeno 26. siječnja 2018).

Društvo (Društvo za istraživanje trostrukog logora Jasenovac). 2018. Društvo započelo provedbu projekta s podrškom Ministarstva hrvatskih branitelja. https://drustvojasenovac. wordpress.com/ (pristupljeno 26. siječnja 2018).

D.Š./V.Š. 2013. Treba promijeniti cijelu preambulu Ustava. Dnevnik.hr, 12.prosinca 2013. https://dnevnik.hr/ vijesti/hrvatska/sabor-pocinje-raspravu-o-ustavnim-promjenama---314968. html. (pristupljeno 19. siječnja 2018).

Đurašković, Stevo. 2008. Politike povijesti: pregled razvoja discipline u Hrvatskoj i Slovačkoj. Politička misao. (45) 3-4: 201- 220.

Đurašković, Stevo. 2013. The Politics of History in Croatia and Slovakia in the 1990s (doktorska disertacija). Ljubljana: Fakulteta za družbene vede Univerze v Ljubljani.

Đurašković, Stevo. 2015. Ako se komunizmu oduzme antifašistička legitimnost, Europa ostaje gotovo bez antifašista! Forum, 23. lipnja 2015. http:// www.forum.tm/vijesti/ ako-se-komunizmu-oduzme-antifasisticka-legitimnost-europa-ostaje-gotovo-bez-antifasista-3352. (pristupljeno 23. siječnja 2018).

Đurašković, Stevo. 2016a. The Politics of History in Croatia and Slovakia in the 1990s. Zagreb: Srednja Europa.

Đurašković, Stevo. 2016b. National Identity-Building and the "Ustaša-nostalgia" in Croatia: the Past that Will not Pass. Nationalities Papers. (44) 5: 772-788.

ERR (Eesti Rahvusringhääling) 2017. President Kaljulaid not in Favor of Building Monument to Konstantin Päts. News, 20. January 2017. http:// news.err.ee/120421/president-kaljulaid-not-in-favor-of-building-monu- ment-to-konstantin-pats (pristupljeno 14. prosinca 2017).

Francois, Etienne. 2006. Velike pripovijesti i lomovi brana sjećanja. Sjećanje na Drugi svjetski rat između nacionalizacije i univerzalizacije. U: Brkljačić, Maja, Prlenda, Sandra. (ur.). Kultura pamćenja i historija. Zagreb: Golden marketing - Tehnička knjiga, str. 221235.

Gagnon, Vernon P. 2004. The Myth of Ethnic War: Serbia and Croatia in the 1990s. Ithaca i London: Cornell University Press.

Gross, Mirjana. 1981. Nacionalno-integracijske ideologije u Hrvata od kraja ilirizma do stvaranja Jugoslavije. U: Gross, Mirjana. (ur.). Društveni razvoj u Hrvatskoj od 16. stoljeća do početka 20. stoljeća. Zagreb: Sveučilišna naklada Liber, str. 283-304.

Haupt, Heinz-Gerhard, Kocka, Jürgen. 2004. Historijska poredba: metode, zadaci i problemi: uvod. U: Roksandić, Drago. (ur.). Uvod u komparativnu historiju. Zagreb: Golden marketing - Tehnička knjiga, str. 147-176.

Hr.n1.info.com. 2017. Odluka a o osnivanju Vijeća za suočavanje s posljedicama vladavine nedemokratskih režima. 1-4.http://hr.n1info.com/Binary/90/ Odluka-o-osnivanju-Vijece-za-suocavanje-s-posljedicama-vladavine-nedemokratskih-rezima.pdf (pristupljeno 20. siječnja 2018).

Hrvatski sabor. 1996. Zakon o naknadi imovine oduzete za vrijeme jugoslavenske komunističke vlasti. Narodne novine, 92/1996. https:// narodne-novine.nn.hr/clanci/sluzbeni/1996_10_92_1600.html (pristupljeno 10. siječnja 2018).

Hrvatski Sabor. 2005. Deklaracija o antifašizmu. Narodne novine, 51/2005. https://narodne-novine.nn.hr/clanci/ sluzbeni/2005_04_51_971.html (pristupljeno 19. siječnja 2018). 
HRT (Hrvatska radio-televizija). 2016. Hasanbegović, kandidat za ministra kulture: Antifašizam je floskula i nema ga u Ustavu. Vijesti, 21. siječnja 2016. http://www.hrt.hr/318376/vijesti/ hasanbegovic-kandidat-za-ministra-kulture-antifasizam-je-floskula-i-nema-ga-u-ustavu (pristupljeno 16. siječanja 2018).

Hudelist, Darko. 2015. Tomislav Karamarko - Moj antikomunistički manifest. Globus, 22. svibnja 2015.

Index.hr. 2004. Premijer Sanader posjetio spomen područje Jasenovac. Index.hr, 16. ožujka 2004.http://www. index.hr/vijesti/clanak/premijer-sanader-posjetio-spomen-podrucje-jasenovac/191514.aspx? mobile $=$ false. (pristupljeno 19. siječnja 2018).

Ivančić, Viktor. 2003. Lomača za protuhrvatski blud: ogledi o tudmanizmu. Split: Kultura \& Rasvjeta.

Kadrov, Kruno. 2006. "Zapamtite Vukovar": Sjećanje, mjesto i nacionalna tradicija u Hrvatskoj. U: Ramet, Sabrina, Matić, Davorka. (ur.). Demokratska tranzicija u Hrvatskoj; transformacija vrijednosti, obrazovanja, mediji. Zagreb: Alinea, str. 65-87.

Kattago, Siobhan. 2009. War Memorials and the Politics of Memory: the Soviet War Memorial in Tallinn. Constellations. (16) 1:150-166.

Kello, Karl, Vilu, Arvo. 2000. The First Red Year - Part 1 of 7 Occupations in the Recent History of Estonia 19401990. Kistler: Risto Eesti Sihtasutus. https://www.youtube.com /watch?v=oz7gKjYDuRg (pristupljeno 21. ožujka 2018).

Kocka, Jürgen. 2004. Asimetrična historijska poredba: slučaj njemačkog Sonderwega. U: Roksandić, Drago. (ur.). Uvod u komparativnu historiju. Zagreb: Golden marketing - Tehnička knjiga, str. 147-176.
Kolb, Mathias. 2005. Looking for the truth behind Lihula. The Baltic Times, 27. travnja 2005. https://www.baltictimes.com/news/articles/12586/ (pristupljeno 13. prosinca 2017).

Komisija (Estonian International Commission for the Investigation of Crimes against Humanity) 2004. The Soviet Occupation of Estonia in 1940-1941. http://www.mnemosyne. ee/hc.ee/pdf /conclusions_en_19401941.pdf (pristupljeno 19. ožujka 2018).

Komisija (Estonian International Commission for the Investigation of Crimes against Humanity) 2008. The Soviet Occupation of Estonia from 1944. http://www.mnemosyne.ee/ hc.ee/pdf/conclusions_en_1944-.pdf (pristupljeno 19. ožujka 2018).

Kuodyte, Dalia. 2012. The tragic story of how one third of Lithuania's population became victims of Soviet terror. Vilnews.com 7. siječnja http:// vilnews.com/2011-12-the-tragicstory-of-how-one-third-of-lithuania$\% \mathrm{E} \% 80 \% 99$ s-population-becamevictims-of-soviet-terror-2 (pristupljeno 21. ožujka 2018).

Kus, Larissa i dr. 2013. Relative Deprivation Versus System Justification: Polemical Social Representations and Identity Positioning in a post-Soviet Society. European Journal of Social Pshycology. (43) 5: 423-437.

Lehti, Marko i dr. 2008. Never Ending Second World War: Public Performances of National Dignity and Drama of the Bronze Soldier. Journal of Baltic Studies. (39) 4: 393-418.

Maak, Gert. 2008. In Europa. 1945 - Joegoslavië. U: Maak, Gert. In Europa (e. 21). Hiversum: VPRO.

Mark, James. 2008. Containing Facism. History in Post-Communist Baltic Occupation and Genocide Museums. U: Sarkisova, Oksana, Apor, Peter. 
(ur.). Past for the Eyes: East European Representations of Communism in Cinema and Museums after 1989, Budimpešta: CEU Press, str. 335-369.

N1 Hrvatska. 2016. Keleminec u Srbu poveo skandiranje - Za dom spremni. Vijesti N1, 27. srpnja 2016. http://hr.n1info.com/a140005/Vijesti/ Keleminec-u-Srbu-poveo-skandiranje-Za-dom-spremni.html. (pristupljeno 20. siječnja 2018).

Osborn, Andrew. 2004. Estonia Accused of Anti-Semitism after Memorial is Erected to 'SS Executioner. Independent, 25. May 2004. http://www.independent.co.uk/news/ world/europe/ estonia-accused-of-anti-semitism-after-memorial-is-erected-to-ss-executioner-564715.html (pristupljeno 27. prosinca 2017).

Pavlaković, Vjeran. 2008. Red Stars, Black Shirts: Symbols, Commemorations, and Contested Histories of World War Two in Croatia. Working paper. Croatian National Bank, str. 1-36.

Pavlaković, Vjeran. 2014. Fullfiling the Thousand-Year-Old Dream: Strategies of Symbolic Nation Building in Croatia. U: Kolstø, Pål. (ur.). Strategies of Symbolic Nation-Building in South Eastern Europe. Farnham i Burlington: Ashgate, str. 19-51.

Pääbo, Heiko. 2015. 1944 vs. 9 May - An Attempt at Reconciliation Instead of Vigorous Glorification: Estonia Commemorating WWII in 2015. Cultures of History Forum. 25. October 2015. http://www.cultures-of-history.uni-jena.de/debates/ estonia/1944-vs-9-may-an-attemptat-reconciliation-instead-of-vigorous-glorification-estonia-commemorating-wwii-in-2015/ (pristupljeno 11. prosinca 2017).

Pääbo, Heiko. 2008. War of Memories: Explaining "Memorials War" in Estonia, Baltic Security and Defense Review. (10) 3: 5-28.
Perica, Vjekoslav. 2006. Balkanski idoli: religija $i$ nacionalizam u jugoslavenskim državama. Beograd: Krug.

Pilić, Damir. 2013. Na mladima svijet zastaje. Slobodna Dalmacija, 26. listopada 2013.

Radelić, Zdenko. 2006. Hrvatska u Jugoslaviji 1945.-1991: od zajedništva do razlaza. Zagreb: Hrvatski institut za povijest i Školska knjiga.

Riigikogu (Estonian Offical Gazzete). 1995. Citizenship Act. https://www. riigiteataja.ee/en/eli /503022016004/ consolide (pristupljeno 10. prosinca 2017).

RT (Autonomous non-profit organization (ANO) "TV-Novosti"). 2011. Estonia Keeps Anti-Fascists away from SS Veterans' Meeting, 30. July 2011. https://www.rt.com/news/ss-division-celebration-activists/ (pristupljeno 7. svibnja 2017).

RT (Autonomous non-profit organization (ANO) "TV-Novosti"). 2017. Perversion of History: Russian officials blast NATO film glorifying Nazi collaborators, 13. July 2017. https:// www.rt.com/politics/396208-historical-perversion-russian-officials-blast (pristupljeno 4. studenoga 2017).

Rudling, Per Anders. 2012. The WaffenSS as Freedom Fighters. The Algemeiner, 31. Siječnja 2012. https://www.algemeiner.com/2012/01/31/the-waffenss-as-freedom-fighters/. (pristupljeno 28. prosinca 2017).

Sedlar, Jakov. 2008. Tudman: film koji vas ne će detuđmanizirati. Zagreb: Hrvatsko slovo.

Smith, David J. 2008. Woe from Stones: Commemoration, Identity, Politics and Estonia's 'War of Monuments. Journal of Baltic Studies. (39) 4: 419430.

Taylor, A. J. P. 1990. Habsburška monarhija 1809-1918. Zagreb: Znanje. 
Šiber, Ivan. 1998. Povijesni i etnički rascjepi u hrvatskom društvu. U: Kasapović, Mirjana i dr. (ur.). Birači i demokracija. Utjecaj ideoloških rascjepa na politički život. Zagreb: Alinea, str. 51-95.

Tamm, Marek. 2013. In Search of Lost Time: Memory Politics in Estonia, 1991-2011. Nationalities Papers. (41) 4: 651-674. 2013.

Traynor, Ian. 2010. Patriots or Nazi collaborators? Latvians March to Commemorate SS Veterans. The Guardian: International Edition, 16. ožujka 2010. https://www.theguardian.com /world/ 2010/mar/16/latvians-march-commemorate-ss-veterans. (pristupljeno: 30. listopada. 2017).

Tuđman, Franjo. 1990. Programske zasade i ciljevi HDZ. Uvodno izlaganje na 1. općem saboru HDZ 24-25. veljače 1990. U: Đurić, Dragan i dr. (ur.). Stranke u Hrvatskoj. Zagreb: Radničke novine, str. 72-83.

Turčin, Kristina. 2015. Poražavajući rezultati istraživanja: Tri četvrtine hrvatskih tinejdžera drži da NDH nije bila fašistička, a pola da su homoseksualci bolesni. Jutarnji list, 30. ruj- na 2015. https://www.jutarnji.hr/vijesti/hrvatska/porazavajuci-rezultatiistrazivanja-tri-cetvrtine-hrvatskihtinejdzera-drzi-da-ndh-nije-bila-fasisticka-a-pola-da-su-homoseksualcibolesni/ 171178/ (pristupljeno 20. siječnja 2018).

Weekes, Lorraine. 2017. Debating Vabamu: Changing names and narratives at Estonia's Museum of Occupations, Cultures of History Forum, 25. Svibnja 2017. http://www.cultures-of-history. uni-jena.de/debates/estonia/debating-vabamu-changing-names-andnarratives-at-estonias-museum-of-occupations/ (pristupljeno 29. prosinca 2017).

Wulf, Meike. 2008. The Struggle for Official Recognition of Displaced Group Memories in Post-Soviet Estonia. U: Kopeček, Michal. (ur.). Past in the Making: Recent History Revisions and Historical Revisionism in Central Europe after 1989. Budimpešta i New York: CEU Press, str. 221-238.

Žerjavić, Vladimir. 1992. Opsesije i megalomanije oko Jasenovca i Bleiburga: gubici stanovništva Jugoslavije u drugom svjetskom ratu. Zagreb: Globus. 


\section{The Politics of History in Estonia and Croatia: World War II as "The Past That Will Not Pass"?}

Abstract This article offers a comparison of the politics of history of WWII in Estonia and in Croatia after their independence. Following an introduction demonstrating how Estonian and Croatian national integrative processes were predominantly marked by their "pursuit" of independency, the main thesis is exposed - that the revisionist memory of Estonian and Croatian Axis fighters as "fighters for the nation and the state" has survived primarily due to the exclusivist understanding of the Soviet Union and Yugoslavia as the Greater-Russian or Greater-Serbian "dungeons" of Estonian and Croatian people, respectively. Although the official historical memory in both countries highlights the European anti-fascist heritage, the authorities' reluctance to move away from the exclusive statehood politics of history serves to promote a positive interpretation of Estonian and Croatian fascism. The authors in conclusion depict the differences between the two countries and warn of the fatal consequences of the current European policies towards totalitarianism as a pattern for dealing with World War II, which are pushing Estonia and Croatia further away from facing the past.

Key words Estonia, Croatia, World War II, the politics of history, remembrance, memory 
